\title{
ASSESSMENT OF THE NET EFFECT OF THE ACTIVE LABOUR MARKET POLICY IN BULGARIA*
}

\author{
Atanas Atanassov ${ }^{* *}$ \\ Silvia Trifonova ${ }^{* * *}$
}

Received: 1. 9. 2019

Review

Accepted: 29.11. 2020

UDC 331.5.021(497.2)

DOI: https://doi.org/10.30924/mjcmi.25.2.15

\begin{abstract}
The assessment of the net effect of active la-

can be seen among those with primary or no edubour market policy contributes to the effective use of public funds in order to achieve optimal results and provide opportunities for future changes in the priority areas of the employment action plans. The paper examines the basic concepts for assessing the net effect of active labour market policy and assesses the net effect of this policy in Bulgaria. In the process of assessing the impact of active labour market policy at the individual level for each program and measure included in the National Employment Action Plan in 2015 and funded from the state budget, the gross effect, deadweight effect, the substitution and displacement effects are estimated. The quasi-experimental design method is applied to assess the net effect of programs and measures on the labour market in cation Regarding age, the highest net effect is observed among young people up to 24 years of age. As related to the duration of unemployment, the highest net effect can be seen among long-term unemployed people (over 24 months). In terms of working capacity, the highest net effect is observed among people with reduced working capacity. Regarding the type of settlement, the highest net effect can be seen in rural areas. The paper provides a number of conclusions and recommendations for increasing the effectiveness of active labour market policy and for improving the state of the labour market in Bulgaria. The analysis shows that in Bulgaria it is necessary to maintain the variety of different programs and measures on the labour market, covering different target groups.
\end{abstract} Bulgaria. The estimation results demonstrate that the total net effect has the value of $14.5 \%$. The net effect for women is significantly higher than for men. Regarding education, the highest net effect

Keywords: active labour market policy, net effect, assessment, unemployment programs and measures

\footnotetext{
* A previous version of this paper has been presented and discussed at the 13th International Conference "Challenges of Europe: Growth, Competitiveness, Innovation and Well-Being", organized by the Faculty of Economics, Business and Tourism Split, in May 2019. Management - Journal of Contemporary Management Issues is one of the supporting journals of the Conference. All the papers have been reviewed and revised, according to the standards of this Journal. The paper is prepared as a part of the research activities under the project "The innovative unconventional monetary policy of the central banks and its effects on the developed and emerging countries, with an emphasis on Bulgaria" (Project No. DN15/10, 2017), financed by the Bulgarian National Science Fund.

** Atanas Atanassov, PhD, Associate Professor, University of National and World Economy (UNWE), Studentski Grad "Hr. Botev", "8 December" Blvd., 1700 Sofia, Bulgaria, Phone: ++ 359888835 902, Fax: ++359 2441 09 39, E-mail: atanassov@econometrica.bg, ORCID: https://orcid.org/0000-0002-2115-2594

${ }^{* * *}$ Silvia Trifonova, PhD, Professor, University of National and World Economy (UNWE), Studentski Grad "Hr. Botev", "8 December" Blvd., 1700 Sofia, Bulgaria, Phone: ++359 888438 709, Fax: ++ 359296239 03, E-mail: trifonovasilvia@yahoo.com; strifonova@unwe.bg, ORCID: https://orcid.org/0000-0001-5145-5986
} 


\section{Journal of Contemporary Management Issues}

\section{INTRODUCTION}

In the last few years, the importance of active labour market policy (ALMP) has increased significantly. This policy is gaining increasing interest from stakeholders (unemployed, employed, employers, etc.) and from the government itself. ALMP is a labour market regulator and is a basic element of any National Employment Action Plan (NEAP), as an appropriate measure and tool to tackle unemployment. The ALMP is a fundamental tool for counteracting high unemployment, and hence for reducing poverty and overcoming social isolation, as it leads to higher qualifications and better employment of the labour force, adapting it to the changing situation on the labour market, and providing incentives to entrepreneurship and the economic initiative. For the EU member states, ALMPs constitute a central part of their European Employment Strategy, which defines employment as one of the key objectives of a joint economic policy in the European Union (EU) (Kluve, J., 2010).

OECD countries have a long and rich experience with ALMPs. The OECD has been collecting comparable public expenditure data on labour market measures from member countries since 1985. As Betcherman et al. (2004) argue, in recent years, knowledge about the impact of ALMP has been steadily increasing, but much remains to be learned, especially in the context of developing countries and countries in transition. The present study attempts to fill this gap by focusing on the ALMP in Bulgaria.

The government of the Republic of Bulgaria has been investing significant financial resources in the implementation of active programs and measures on the labour market, such as subsidized employment, training, and financial support for the unemployed persons' start-ups. This aims to encourage employment, to speed up filling in job vacancies, and to support those groups, which remain in a state of persistent unemployment, with a trend toward impoverishment. The effective distribution of the funds provided by the State Budget (SB) for the implementation of the ALMP is particularly important for achieving maximum results that are beneficial both to the unemployed participating in the programs and measures, as well as to the employers and to the society as a whole.

This paper explores the impact of the ALMP in bridging the employability gap of the unemployed in Bulgaria. The aim of the study is to obtain a net assessment of every program and measure for training and employment by eliminating the eventual impact of other side factors. The main hypothesis of the study is that the programs and measures of the ALMP in Bulgaria have a positive effect. Moreover, the effect is probably different for different groups of unemployed people.

All programs and measures, included in the NEAP, are the object of the study. The vision of the NEAP is related to hastening the transition from unemployment to employment in the real economy, including the vulnerable social groups into the labour market, especially those from the least developed regions in the country, and to reducing the mismatch between labour supply and demand.

A study of the net effect of ALMP in Bulgaria is conducted every few years, in order to obtain assessments for updating programs and measures included in the ALMP. The last assessment of the net effect of ALMP in Bulgaria was conducted in 2017. The paper covers programs and measures that were included in the NEAP in 2015 , as to capture the long-term effects, 
it is necessary to conduct the study at least one year after the end of the program and its measures.

The results of the study will contribute to improving the quality and effectiveness of ALMPs, as well as to updating the information needed for the decision-making process in the field of ALMP. The results are interesting for the current policymakers, because they update the programs and measures included in the NEAP on an annual basis. The results have already been made available to the Ministry of Labour and Social Policy of the Republic of Bulgaria. who have taken them into account. This helps reduce the mismatch between labour demand and labour supply in Bulgaria.

\section{AN OVERVIEW OF THE ACTIVE LABOUR MARKET POLICY IN BULGARIA}

The Bulgarian active labour market policy includes a wide range of programs, projects, schemes and measures that have several purposes:

- Improving and/or acquiring practical skills through on-the-job training;

- Improving the qualification level of both the unemployed and the employed in order to facilitate their adaptation and to meet the requirements of the labour market;

- Insuring conditions for temporary and permanent employment;

- $\quad$ Preventing the risk of unemployment;

- Supporting the inclusion of people from disadvantaged social groups into the labour market;

- $\quad$ Decreasing unemployment;
- Increasing employability;

- Encouraging entrepreneurship, economic initiative and adapting the labour force to changing labour market conditions and requirements;

- Reducing poverty;

- Decreasing and preventing social isolation.

Active labour market policy programs and measures are based on the longterm priorities set out in the Europe 2020 Strategy. They operate toward the maintenance of financial stability and provide opportunities to improve the business environment in Bulgaria. ALMP aims to help both the unemployed and vulnerable groups, as well as the employers in the overall development of the labour market. Programs and measures, aimed at the unemployed and people from vulnerable groups can be considered both as an opportunity to provide social protection and social inclusion, and as an opportunity for people from these groups to work for their own income and provide them with social security rights. Furthermore, these programs and measures also have a partial impact on improving the revenue from taxes and social security contributions of the state itself. By subsidizing a portion of the labour costs of the companies in Bulgaria, the state provides them with real support, helps create jobs, and ensures better prospects for the development of the labour market (see: Atanassov, 2016).

The need to assess the effects of ALMPs stems from the fact that public funds are spent at a time of an economic crisis and under the operating currency board arrangement in Bulgaria, the aim being to achieve optimum results. In addition, the results will indicate the necessary changes to be made in the higher priority sections of the 


\section{Journal of Contemporary Management Issues}

NEAP related to the development and improvement of ALMPs.

The efforts to increase employment and reduce social exclusion in the country continue to be important due to the need for reducing unemployment, especially among vulnerable groups in the labour market, and for increasing the adaptability of the unemployed and the employed.

\section{THEORETICAL}

\section{FRAMEWORK AND}

RESEARCH METHODOLOGY OF THE NET EFFECT

\section{ASSESSMENT}

This section presents the theoretical framework and research methodology, used for the subsequent assessment of the effect of ALMP at the individual level (net effect). Borate et al. (2014) define evaluation as a systematic way of valuation, which ultimately gives the necessary information required for the continuous improvement and growth. The rationale behind the selected approach that makes an overall assessment of the effect from the ALMP at the individual level is to compare the various results that have been obtained from the study, thus, making it possible to arrive at and analyze the various effects. In the process of assessing the impact of ALMP at the individual level for each program or measure, the gross effect, the deadweight effect, the substitution and displacement effects are calculated. In the final account, the net effect from the programs and measures for employment and training financed from the state budget are obtained.

\subsection{Gross Effect (GE) from the implemented programs and measures}

The gross effect (GE) from the implementation of a program/measure is determined by the number of the unemployed persons (or their relative share), who have been included in a given program/measure, and who have achieved a result expressed in their subsequent employment.

$$
\mathrm{GE}=\mathrm{p}_{\mathrm{t} 1} \text {, }
$$

Where $G E$ is the gross effect, and $\mathbf{p}_{\mathrm{t} 1}$ is the relative share of people from the socalled test group who managed to find a job during the study (see: Econometrica, 2017).

The test group for each program/measure is formed as a representative sample, or it encompasses all the persons who have been included in the program/measure, if there were less than 300 participants included altogether. A test group has been formed for each program/measure that is included in NAPE 2015, financed from the state budget (SB). The construction of these test groups is described in detail below in connection with the so-called quasi-design of the experiment, while the sample volumes are indicated in the sample formation methodology.

The relative share is calculated as the ratio of the number of people who indicated that they found a job from the test group $m$, to the total number of people studied in the group $\mathrm{n}$ :

$$
\mathrm{p}_{\mathrm{t} 1}=\frac{\mathrm{m}}{\mathrm{n}} \text {. }
$$

Here, it is assumed that the respondents were unemployed and registered with the labour offices before participating in the 
programs and measures. These people were subsequently included in employment and training programs and measures. By means of quantitative study, it was established what percentage of these people were able to find work within one year, completing their participation in a program/measure, i.e. those for which the program/measure has been effective (Ministry of Labour and Social Policy of the Republic of Bulgaria, 2015).

The GE of the programs and measures on the income of the persons from repeated employment is measured by the average increase of the income that they received.

However, the gross effects cannot indicate whether the result achieved is due only to the impact of the program/measure, or if it is also due to other factors, as some of the unemployed may find work and receive income from multiple employments, even without the help of the program or the measure. Possible factors that may influence employment are: labour market trends, seasonal employment, amount of personal effort in seeking employment and so on. The question arises: "What would have happened to these unemployed had they not been included in the programs and measures on the labour market?" To answer this question, it is necessary to assess the net effect from a program/measure, i.e. the effect which is due only and uniquely to the studied active programs and measures.

While a program/measure may have a positive impact at individual level (for individuals), its impact at national level may be quite different. That is the reason why the effects described below should also be taken into account. There is a vast body of literature on these effects, such as OECD (1993), Fay (1996), Martin (2000), Martin and Grubb (2001), Sahnoun and Abdennadher (2018) and others.

\section{2. "Deadweight Effect" (deadweight loss - DW)}

This effect concerns those cases, where the unemployed persons would have been hired by the same employers even without the subsidy, i.e. the result from the program/ measure would have occurred without a specific intervention. In employment studies, "deadweight" is measured by the number of unemployed people (or their relative share $\mathrm{P}$ ) from the control group) who were not included in the specific program / measure, but still managed to achieve a result, i.e. they found a job. Thus, we have:

$$
\mathrm{DW}=\mathrm{p}_{\mathrm{C} 1} \text {, }
$$

where DW stands for the "deadweight" loss, and $p_{C_{1}}$ is the relative share of the persons from the control group who found a job. The rationale behind the construction of the control group is described below.

\subsection{Displacement effect (DS)}

This effect is observed in those cases, where the actions of an employer, participating in a given program or measure, have a negative effect on the actions of another employer, who does not directly participate in the program/measure. It is possible for an organization or a company with subsidized employees to increase its production volume, thanks to the advantages, resulting from the reduced labour costs. This would, in turn, lead to a decrease in the production volume of competing organizations (companies), which are forced to reduce their personnel, as a result of this displacement effect. With regard to the evaluation of this effect, Johannesson and Wadensjo (1995) point out that it can be done both at the micro- and at the macroeconomic levels. The evaluation at the microeconomic level is carried out by comparing the production 


\section{Journal of Contemporary Management Issues}

volumes of companies from the test group and from the control group, while at the macroeconomic level aggregated evaluations of sectors of the economy should be done. Haveman and Hollister (1991) examine several different methods that have been successfully applied to assess the displacement effect:

- A quantitative survey of persons involved in employment and training programs and measures conducted among employers. This study can be conducted at the microeconomic level.

- Estimation by modeling the labour force demand function. This approach is a macroeconomic and the aim is to use an econometric model to assess the impact of active policies/measures on the labour market. The method has been successfully applied in many countries, such as the United States, Australia, France and others in the 1970s and 1980s and was described by Lewis and Ryan (1985) and Kopits (1978). When examining the effects of the active labour market measures in Sweden, Krueger and Forslund (1994) suggest using the following linear-logarithmic econometric model:

$$
\begin{aligned}
\mathrm{E}= & \beta_{0}+\beta_{1} \mathrm{PRW}+\beta_{2} \operatorname{lnW} \\
& +\beta_{3} \mathrm{X}+\mu+\tau+\varepsilon,
\end{aligned}
$$

- where $\mathrm{E}$ is the employment variable, PRW are the total number of public relief workers in county, InW is a natural logarithm the average real wage and $\mathrm{X}$ is a vector of cyclical demand measures, such as the unemployment rate and the vacancy rate. They also include unlimited country fixed effects ( $\mu$ ) and unlimited annual effects $(\tau)$. In this way, the estimated value of the parameter $\beta_{2}$ will show what is the value of displacement effect.
- A quantitative study among two groups of employers: (1) employers who employed persons who took part in the programs/measures, and (2) employers who did not employ such persons. This study is, again, based on the principle of comparing a control group to a test group. The contractor uses this approach, although it is usually difficult in companies to find a "twin", and the firms that hire persons participating in the programs / measures differ depending on how many people from the studied programs / measures are employed, for how long, with what qualifications, etc. In relative terms, the displacement effect is the number of dismissed persons from the companies from the control group, divided by the number of persons included in the programs/ measures of NEAP.

\subsection{Substitution Effects (SE)}

The substitution effects (SE) are in place, when a given employer employs a subsidized worker, who has been dismissed or has never been employed in the place of a regular worker. To estimate this effect, a situation is hypothetically recreated, for which it is established whether the programs/measures for employment were not in place, the employers would be ready to dismiss a worker and employ again the same person, or would the employer employ another person in the place of the former (Ministry of Labour and Social Policy of the Republic of Bulgaria, 2015). On the other hand, it must be identified whether the person, who has been employed, could begin to work in the same job, without the active program/measure. In order to recreate such a situation, information is simultaneously combined from the following sources: 
- Gathering of information from the employers, concerning whether, in order to appoint an employee/worker, they had dismissed another one, or would they employ an additional person. In order to gather this information, firstly, employers of the persons from the test group, who took part in the programs or measures for employment and training, had to be identified. Secondly, the employers were contacted by phone and interviewed, regarding the issue of whether they had dismissed an employee, in order to employ this employee/ worker, or they would employ another person. As to gather this information, the computer assisted telephone interviewing (CATI) was used.

- The second source of information are the people who have taken part in the active labour market measures and have started to work. The questionnaires include questions about whether they would start the current job, without participating in the active program or a measure.

- Since the situation to be recreated is hypothetical, in order to establish and assess the real world situation, a third key component for the assessment of the substitution effect has to be included, namely, how probable it is for the two previous events to occur. To evaluate the probability, a scale is used for the evaluation of the substitution effect and the following formula:

$$
E(S E)=X_{i} P_{i},
$$

where $E(S E)$ is the mathematical expectation of the substitution effect, $X_{i}$ are the substitution cases, $P_{i}$ is the probability for them to occur and with $i$ are denoted the studied programs and measures included in the NEAP.

\subsection{Net Effect from the implemented programs and measures (NE)}

After the evaluation of all above-mentioned effects, it is possible to obtain the net value of each program and measure for training and employment funded by the SB, eliminating the possible impacts from the other side factors. This makes it possible to confirm that the estimated net impact is the result of solely the active labour market programs and measures, as well as to establish precisely and clearly what would actually happen in the labour market, if these programs and measures were not implemented. Thus, it is proven that finding a job and increasing one's income is due solely to the participation of the unemployed persons in the program or measure:

\section{$\mathrm{NE}=\mathrm{GE}-\mathrm{DW}-\mathrm{SE}-\mathrm{DS}$,}

where $N E$ is the Net Effect, $G E$ - the Gross Effect, $D W$ - the "Deadweight" Effect, $S E$ - the Substitution Effect, and $D S$ is the Displacement Effect.

The studied programs and measures, included in the NEAP of Bulgaria and financed with funds from the SB, have been ranked according to their effectiveness. The evaluation of their effectiveness has taken into account the opinions of the included persons from the target groups. For this purpose, ranks placed in descending order were used, with the programs and measures for which the highest net effect of the implemented ALMP is observed being in the first place, and the least effective programs and measures taking the last place.

After gathering the data, an analysis is made not only according to programs and measures for employment and training, but also by groups of participants, using the following main characteristics:

- Gender; 


\section{Journal of Contemporary Management Issues}

- Age;

- Level of education;

- Disabled persons;

- Qualification;

- Other characteristics.

The obtained results should be interpreted, bearing in mind that the data on the majority of the active labour market programs and measures (those with over 300 participants) were drawn from a representative sample, not from each individual participant in the program/measure. Still, the conclusion reached is valid for the whole "statistical population" and is guaranteed with $95 \%$ of probability in the present study. This proves that the implemented active labour programs and measures were effective, but it also indicates for which group of participants this effect was significantly greater (see: Kish, 1965).

\section{ASSESSMENT METHODS BASED ON INTERNATIONAL EXPERIENCE AND GOOD PRACTICES}

Theoretical and methodological research and empirical confirmations of the real net effect of a program or measure on the labour market show that various methods are used to assess the net effect of ALMPs. The application of each of them requires the collection of statistical data, which can be obtained from administrative sources or through a specially planned quantitative survey. The best way is to combine these two sources, thus obtaining the most complete picture of the implemented programs and measures for employment and training.

When studying the active programs and measures on the labour market, the administrative data on the persons which are collected in the labour offices are combined with the quantitative research on the effects of the programs and the measures for employment and training. The former is provided by the Employment Agency (EA) of the Republic of Bulgaria.

Many studies have been devoted to the assessment methods. One of the main methods by which the net effect of labour market programs and measures can be assessed is the Design of experiment (DOE) method. The method is widely applicable in a number of fields such as physics, chemistry, psychology, medicine, education, engineering, manufacturing industry, service industry, and many others, including nanotechnologies.

The theory of design of experiment was developed by Charles S. Peirce in "Illustrations of the Logic of Science" (1877-1878) and "A Theory of Probable Inference" (1883). This experimental testing technique is studied by many authors, such as Ashenfelter (1987), Ashenfelter and Card (1985), Heckman and Robb (1985), LaLonde (1986), Fraker and Maynard (1987), Card and Sullivan (1988), Bell et al. (1995), Heckman et al. (1998), Heckman et al. (1999), Krishnamoorthy and Kapadia (1999), Ross and Morrison (2003), Betcherman et al. (2004), Bracken (2006), Card et al. (2009), Mitchell (2016), Atanassov (2017), Antony et al. (2020), and many others. As can be seen, the issue of assessing the effect of a program or measure by using the DOE method is a wellstudied problem with a long history in statistics and econometrics. This is true both in theoretical and applied literature.

Following are some of the main characteristics, advantages and disadvantages of the DOE method (Atanassov, 2017): 
- The DOE method uses two randomly formed stochastic (representative) samples, created from the group of the unemployed persons, to whom a program, or a measure is directed. The two samples must be similar in terms of gender, age, place of residence, education, etc. Out of the two samples, one is the test group, consisting of the persons, who were included in the programs/measures, and the other one is the control group, including persons who did not participate in the studied programs/ measures.

- Both samples should be influenced by the same factors, the only distinguishing feature being their participation in the programs/measures of the active labour market. The results of the test and control groups are compared at the end of the program (usually at least one year later when the effects are expected to take place). The net effect, i.e. the actual effect of the program/measure, is calculated as the difference between the mean values of the two groups.

- The DOE method is not without drawbacks and limitations. The main criticism refers to the fact that the estimates can be affected by the members of the control group being included in other programs or measures in the meantime, the fact that can potentially distort the results. Also, DOE is applicable only if planned and initiated before the start of the programs and measures.

The quasi-experimental design is the other possible method. It presents an advanced form of the classical design of the experiment (see Heckman (1999), Heckman et al. (1999), Meyer (1995), Riddell (1998), Schmidt (1999), Smith (2001), Besley and Case (2000), Blundell and Costa Dias (2000), Imbens (2004), Borland et al. (2005),Kluve (2007), Dinardo (2008), Card et al. (2009), Glitz (2011), Atanassov (2017), and many others).

The following are the main advantages of the quasi-experimental design method over the classical experimental design (Atanassov, 2017):

- This approach is designed specifically for and applied in ex-post evaluations, as the classical experimental design is not applicable;

- Quantitative research shall be carried out only once, usually one year after the end of participation in the programs and measures, thus, overcoming the inconveniences that exist in the simple experimental design, lasting for years;

- Discrimination against the unemployed, with regard to their inclusion or non-admission to the programs and measures for the purpose of conducting the experiment is avoided.

The basic characteristics of the quasiexperimental design method are as follows (Atanassov, 2017):

- Two representative samples are selected, one with persons, who were included in the active programs/measures (test group) and the other, consisting of participants who were not included in the programs/measures (control group).

- In order to be comparable, the two samples should have similar characteristics. For example, if there are more men or urban people in one sample and fewer in the other, it cannot be judged, ultimately, whether finding a job is due to active labour market measures or gender and type of settlement characteristics. 


\section{Journal of Contemporary Management Issues}

The Propensity Score Matching method is the approach used in the paper, in order to obtain two samples with the same or very similar characteristics. This is a statistical method that ensures finding pairs of individuals from the test and control groups, who have similar characteristics. This is not done by matching each feature separately, but by forming groups of individuals, using probabilistic models which ensure similarity and the likelihood of being included in the control or test group is the same. Rosenbaum and Rubin (1983) prove that this method is extremely convenient for forming a test and control group in the subsequent evaluations of the effects of the implemented programs and measures. The process relies on the information collected by the labour offices and available in the "National database of the labour market and the ESF" of the Employment Agency.

\section{LITERATURE REVIEW IN THE FIELD OF NET EFFECT ASSESSMENT}

Over the last four decades, research on the assessment of active labour market programs has developed significantly. Since the mid-1980s, the OECD has been collecting statistics on ALMP expenditure in its member countries, which have a long and rich experience with ALMPs. As Betcherman et al. (2004) argue, while the knowledge on the impacts of ALMPs continues to grow, there is still much more to learn, especially in the context of developing and transition countries. In this regard, the present study attempts to fill this gap by focusing on the ALMP in Bulgaria.

Numerous studies have been conducted, both from the theoretical and the methodological point of view, applying the econometric and statistical analysis of the effects of ALMPs. In recent years, many studies have assessed the impact of active labour market programs and measures and some of them deserve special attention.

In the case of Bulgaria, the last two assessments of the effects of the ALMP are respectively: (1) "Elaboration of a subsequent assessment of the effect of the active labour market policy financed by state budget resources at individual level (net effect)". Conducted in 2017, this study assesses the programs and measures included in the NEAP in 2015. (2) The second assessment is "Elaboration of a subsequent assessment of the effect of the active labour market policy at individual level". Conducted in 2014, this study assesses the program and measures included in the NEAP in 2011, financed by state budget funds.

There are numerous evaluation studies worldwide on the net effect of the ALMPs. In-depth studies are available to evaluate the effectiveness of ALMPs in the EU member states and other European countries (e.g. Switzerland, Norway, etc.). One such example is Kluve's (2010) empirical analysis, which attempts to identify the most effective types of active labor market programs and measures.

The OECD (1993) survey, encompassing 19 countries, provides a complete picture of the impact of active labour market programs on wage-setting. Fay's (1996) evaluation of the effectiveness of active labour market policies in OECD member countries has shown that ALMPs differ significantly in their goals and impact between the countries and within the countries over time. Program evaluations aim to determine the impact of different ALMPs, both for individuals and for society as a whole. Brown and Koettl (2015) propose a new classification of ALMPs according to their 
objectives, relevance and cost-effectiveness during normal times, crisis and recovery.

Fretwell et al. (1999) evaluated the five most popular ALMPs in four countries in Europe and Central Asia - the Czech Republic, Poland, Hungary and Turkey, in order to determine whether there was any significant difference between those individuals who have participated in active labour programs and similar individuals, who did not participate in programs, in terms of agreed outcome measures of program success (e.g. employment, wage levels). Park et al. (1996) use a quasi-experimental design to estimate the ALMPs' impacts on both employment and hourly wages in Canada. Calmfors (1993) offers an empirical estimation of how the wagesetting schedule is affected by ALMPs in Sweden. In fact, Sweden is the European country with the longest tradition of using ALMP. For Finland, Eriksson et al. (1990) and Calmfors and Nymoen (1990) conducted empirical studies with time series on the relationships between wages and ALMP. Raaum and Torp (2000) used quasi-experimental design and constructed different models to assess the impact of the Norwegian Labour Market Training Program. According to their models the program has yielded positive effects, which are estimated at about $15 \%-20 \%$ of the average post-training earnings.

Heckman et al. (1999) have systematically reviewed a wide range of European evaluation studies, including information on impact assessments and assessment methods. However, they did not perform a statistical analysis of their limited sample. Fitzenberger and Prey (2000) used a quasiexperimental design to assess the impact of public sector training programs on employment and wages in post-unification Germany. Martin (2000) and Martin and
Grubb (2001) have reviewed the experience of OECD countries with active labour market programs. Payne (2000) evaluated the training program for the long-term unemployed in the United Kingdom (UK) using a quasi-experimental design. In a previous study, Payne et al. (1999) also evaluated the skills training program for the long-term unemployed in the UK.

Benus and Rodriguez-Planas (2002) assessed the impact of ALMPs on current employment in Romania using a quasi-experimental design and demonstrated the positive impact of the program $(7 \%$ higher probability of being employed). In their subsequent study, Rodriguez-Planas and Benus (2010) provided estimates of the effects of four ALMPs, implemented in Romania in the late 1990s. The authors found that three of the four ALMPs in Romania (namely, training and retraining program, self-employment assistance program and public employment and relocation services program) were successful in improving participants' economic performance.

Arellano (2010) assessed specific skills training in different sectors using quasiexperimental design and concluded that training courses have a positive effect and reduce the likelihood of remaining unemployed, although they are not as effective as continuing formal education. In their study, Kluve and Schmidt (2002) analyzed the effects of ALMP by program type, study design (experimental versus non-experimental), time period (1980s versus 1990s) and macroeconomic environment. They used the results of 53 recent evaluation studies and applied regression analysis. The authors conclude that programs with high content of training seem most likely to improve the likelihood of employment. 


\section{Journal of Contemporary Management Issues}

Greenberg et al. (2003) used a metaanalysis to synthesize findings from 31 evaluations of 15 voluntary governmentfunded training programs for disadvantaged people that operated between 1964 and 1998. The authors concluded that, on average, the effects of the evaluated programs were the largest for women, modest for men and insignificant for young people. For men and women, the earning effects of training are maintained for at least a few years after graduation. The authors found no evidence of more expensive training programs performing better than the cheaper ones. The study also showed that, although the United States has many years of experience in conducting training programs, the programs have not become more effective over time.

Extensive research has been done by Betcherman et al. (2004) on the impact of ALMPs, especially in developing and transition countries. The study was based on the 72 scientific assessments, reviewed in a previous World Bank study (Dar and Tzannatos, 1999), with the authors adding 87 new studies. The authors found a wide range of ALMP results, with some programs demonstrating positive effects, and the others showing no impact, or even negative effects.

Card et al. (2009) assessed ALMPs, based on approximately 200 European and American micro-econometric assessment studies. The authors classified the assessments, according to the statistical significance of the post-program impact on the participants, i.e. if it was found to be significantly positive, insignificant or negative. Their meta-analysis model assumes that the measured effectiveness of an ALMP depends on the type and duration of the program, characteristics of the participants, and the evaluation methodology. The authors found that job search assistance programs usually have a beneficial effect, especially in the short term, and on-the-job training programs are not favorable in the short-term but have more positive effects after two years.

Imbens and Wooldridge (2008) conducted a study of the latest methodological achievements in program evaluation. The authors have focused on practical issues for empirical researchers and have made a historical overview of the issues of ALMPs. Boone and Van Ours (2009) have analyzed the macroeconomic effects of ALMPs. They made a theoretical analysis of the different types of ALMPs in the context of a searchmatching model. The theoretical findings were confirmed in an empirical analysis using data from 20 OECD member countries. They found that labour market training proved effective in reducing unemployment, while public employment services and subsidized jobs were not effective at all.

Bassanini and Duval (2006) examined the impact of policies and institutions on aggregate unemployment and employment rates in OECD member countries using cross-country/time-series econometric techniques and data for 21 OECD countries for the period 1982-2003. Special attention is paid to the institutional determinants of labour market participation of young, women and older workers. Kluve (2007) analyzed nearly 100 separate studies to evaluate ALMP programs in Europe, most of which have been operational since 1990. In a later analysis, Kluve (2010) made an empirical analysis aimed at identifying the types of active programs that appear to be most effective. He classified the existing ALMPs in European countries into four categories and assessed their effectiveness using a meta-analysis. His empirical analysis is based on a dataset, including 137 program evaluations originating from 96 academic 
studies, conducted in 19 countries in 2005 . The countries that fall within the scope of the study are Austria, Belgium, Denmark, Estonia, Finland, France, Germany, Hungary, Ireland, Italy, Netherlands, Norway, Poland, Portugal, Slovak Republic, Spain, Sweden, Switzerland and the United Kingdom. The author concludes that traditional training programs have a modest likelihood of generating significant positive impact on post-program employment rates.

There is only a limited number of studies that examine the impact of the ALMP in Bulgaria. A notable example is the study by Betcherman et al. (2004), where Bulgaria was studied as a transition country. The authors reveal the problems of the labour market in the country, the intervention projects, the types of assessments and discuss the results obtained. The active programs and measures on the labour market in Bulgaria considered in their study are: "Professional training for unemployed", "Temporary employment program" and "Development of micro-enterprises" in the period 1998-1999.

\section{SURVEY FRAMEWORK USED FOR ESTIMATING THE NET EFFECT}

When doing the subsequent evaluation of the effects of an ALMP at the individual level, it is important to remember that the study should take into account only the persons who had completed their participation in a given program, or a measure, at least one year before initiating the study.

Information about the number of people, covered by the individual programs and measures, as well as their individual identification, are provided by the Employment Agency (EA) in the Republic of Bulgaria, which is an associated project partner, providing the following comprehensive lists:

1. List with the persons, who have participated in the studied programs and measures, from which the test group was formed.

2. List with the persons, who did not participate in the studied programs and measures, from which the control group was formed.

For small program/measures involving less than 300 participants, information has been collected for each participant. In other words, all the participants in the program/measure have been interviewed, or an attempt has been made to interview all of them. As for the large programs, an exhaustive study is not expedient, which is why the stochastic (representative) approach is used.

In choosing the stochastic (representative) samples, the principles of the theory of representative studies have been observed, namely, that each unit (person registered at the Labour Office Directorate) from the studied statistical population would have the same probability of becoming a part of the sample.

The number of persons that were interviewed in individual programs and measures depends on the lists of persons, submitted by the EA and the completeness of the information available to the EA for the unemployed, as well as on refusals, received during the interviews. A total of 4,093 interviews with individuals in the test group and 2,012 interviews with individuals from the control group were conducted for the study.

The sample sizes among employers are respectively: 505 among employers, 


\section{Journal of Contemporary Management Issues}

participating in the NEAP 2015 (test group) programs and measures and 500 others, who did not participate in the programs and measures on the active labour market (control group). Information was gathered from employers through telephone interviews.

\section{RESULTS OF THE NET EFFECT ASSESSMENT OF THE ACTIVE LABOUR MARKET POLICY}

The subsequent assessments of the effects of active labour market policy can produce variable results, but they are mainly done in two directions - toward increasing the chances of subsequent employment and toward increasing the income levels thanks to current (during the programs and measures) and subsequent employment. The two main research questions are: "What changes have the studied programs and measures produced?" and "What would be the situation if the programs and measures had not been implemented?"

\subsection{Gross effect}

Following the completion of the programs and measures included in NEAP 2015, the status of persons in the labour market in 2017 is examined. It takes at least a year for the effect of the labour market programs and measures to become apparent. Thus, the study of the status of the program participants should not start earlier than that. The results of the employment status of the surveyed persons are presented in Figure 1.

Figure 1.Distribution of the studied persons, according to their employment status in 2017 (\%)

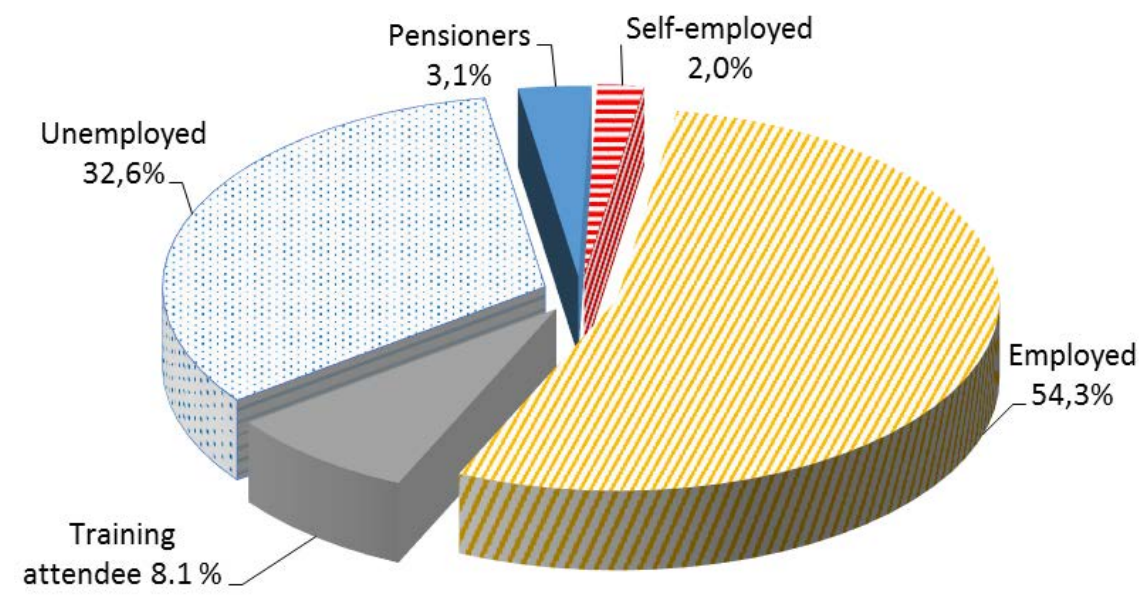

Source: Own estimations.

Most of the people have found a subsequent job, i.e. the labour market program/ measure, in which they participated had a positive effect on them. In 2017, more than half of the surveyed persons $(54.26 \%)$ were employed. To those who had found employment, we should add the self-employed persons $(1.95 \%)$ who have their own business or work independently, as well as retirees $(3.08 \%)$, for whom we can also draw 
the conclusion of a positive effect, as some programs and measures are aimed precisely at helping people to retire ${ }^{1}$. After combining these three groups, it can be said that the programs and measures have had a longterm positive effect for more than half of the studied persons $(59.3 \%)$.

\section{2. "Deadweight Effect"}

As it has already been mentioned, the main question that required an answer in doing the net assessment of active labour market policy was "What would have happened to people if they had not taken part in the programs and measures under assessment?". For this purpose, additional 2,012 persons from the control group were studied. The employment of people from the control group on the labour market is the "Deadweight effect". In order for the two groups to be comparable, participants in both samples had to be registered as unemployed in 2015. Their status on the labour market was established in 2017. Likewise, it was necessary for both groups of participants to have similar characteristics in 2015. The main results of the control group are presented below, including the comparison with the test group.

Table 1. Control group participants' status on the labour market in 2017

\begin{tabular}{|l|c|}
\hline \multicolumn{1}{|c|}{ Status on the labour market } & Relative share (\%) \\
\hline Unemployed & 53.8 \\
\hline Employed & 39.0 \\
\hline Inactive & 5.6 \\
\hline Pensioners & 1.0 \\
\hline Training attendee & 0.5 \\
\hline Self-employed & 0.1 \\
\hline Total & 100.0 \\
\hline
\end{tabular}

Source: Own estimations.

The majority of those who were unemployed in 2015 continue to be unemployed by the end of $2017-53.8 \%$ of all persons in the control group. The second place was occupied by the share of the employed - 39\% of the studied persons. In terms of comparison, at the end of 2017 the share of the employed in the test group (those who took part in the programs and measures on the labour market) was $54.3 \%$. The third group with a relative share of $5.6 \%$ should not be ignored. It consists of the persons who are not actively seeking employment. For comparison, this share in the test group is only $0.1 \%$, which means that the programs and measures on the labour market encourage the program participants to actively search employment.

The net effect is measured not just as a difference between the shares of the employed persons from the two groups (the test and the control groups). It is even larger, because the programs and measures on

\footnotetext{
Such is, for example, the support in Retirement National Program.
} 


\section{Journal of Contemporary Management Issues}

the labour market are directed to the vulnerable share of the unemployed, for whom it is more difficult to find a job. Besides, some additional effects can also be observed, such as substitution and displacement effect, examined below. On the other hand, the comparison of the results of the test and the control groups indicates the most important effects of the ALMP.

\subsection{Substitution effect}

According to the provision of Art. 56, para. 6 of the Employment Promotion Act, job creation under some specific measures could be subsidized, if in the last three months the employer has not terminated employment contracts with employees, working in the same positions as the unemployed. This means that there could be no substitution effect, caused by these measures. In addition, in order to determine more precisely whether the substitution effect had taken place, a survey was carried out among employers, to find out if there had been a change in the number of employees at all, and, thus, to determine whether the substitution effect took place. The ex-post assessment made of the programs and measures included in the NEAP is the second to be done according to this methodology in Bulgaria. To compare the results, the assessment of the substitution effect was again done by surveying the managers of 505 companies and gathering information on how the number of employees has changed.

In order to assess the substitution effect, the survey explored whether the employers had hired subsidized workers in the place of regular workers. For this purpose, the employers from the test group were asked whether the hiring of participants in the program was accompanied by laying off other workers from the company/organization in the next several months.

Table 2. Distribution of the employers according to the substitution effect

\begin{tabular}{|l|c|c|}
\hline Change of the personnel influenced by the measure & Number & Share (\%) \\
\hline $\begin{array}{l}\text { No, our personnel increased by the number of the newly employed } \\
\text { under the program }\end{array}$ & 486 & 96.2 \\
\hline $\begin{array}{l}\text { Yes, we laid off some persons, but less than the number of the } \\
\text { newly employed }\end{array}$ & 3 & 0.6 \\
\hline $\begin{array}{l}\text { Yes, we laid off the same number of persons as the number of the } \\
\text { newly employed }\end{array}$ & 14 & 2.8 \\
\hline No answer/Refusal & 505 & 100 \\
\hline Total & 2 & 0.4 \\
\hline
\end{tabular}

Source: Own estimations.

The substitution effect has a very small impact on the effects of the programs and measures from the NEAP 2015. The reason for this is that almost all companies $(96.2 \%)$ have not laid off a single person due to hiring subsidized workers. Only $0.6 \%$ of them have reported to have laid off workers, but fewer than the employed ones. Only $0.4 \%$ of all companies report to have laid off as many people as they have employed, due to the programs and measures, i.e. the full effect of substitution is present. The total assessed effect of the substitution for all programs and measures is as low as only $0.6 \%$.

The substitution effect was expressed only in socially targeted programs which 
were in support of people with disabilities, such as the Assistants to Persons with Disabilities National Program, where one group of assistants was replaced by another. In other cases, these people are moving towards the same or similar programs, after the completion of the current program, in order to be assistants to people with disabilities (who are, most often, their relatives).

\subsection{Displacement effect}

In order to explore this effect, we examined those cases, where a program or measure on the labour market, had helped employers to increase their volume of production, thanks to the advantage of labour cost savings. Thus, the companies become more competitive, displacing in this way their competitors and causing them to lay off some workers. The displacement was established both through the study among the employers, who have hired unemployed persons under the programs and measures (the test group), as well as among their competitors (the control group).

National programs and projects in the labour market have not shown a particularly large displacement effect. This effect is zero for the Assistants to Persons with Disabilities National Program, as well as for the Career Start Program, where it is difficult to talk about any competition. A more significant effect is observed for the "Beautiful Bulgaria" project, where about a fifth of the companies reported to have exerted some little impact on their competitors, but this had in no way impacted the competitors' volume of production and number of employees.

The overall estimated displacement effect is $4.1 \%$. It is influenced by the structure of the Bulgarian economy and in particular by the specific sectors in which the persons from the studied programs and measures are employed.

\subsection{Net effect}

Having assessed all the above-mentioned effects, it is possible to obtain the net assessment of every program and measure for training and employment by eliminating the eventual impact of other side factors. It is also possible to compare the effects on different socio-demographic groups on the labour market in the country. The obtained net assessments show the actual level of efficiency of the programs and measures included in the NEAP 2015.

As indicated above, the share of persons from the test group who participated in the programs and measures of NEAP 2015 and who achieved successful realization on the labour market (employed and self-employed people together) was $59.3 \%$. The same share from the control group was $40.1 \%$, which is 19.2 percentage points (p.p.) below the test group's result. This means that the participants in the programs and measures have had about $50 \%$ greater chances of realization than if they had not been included in the active measures on the labour market.

Since the assessed overall gross effect in terms of subsequent employment after the completion of the studied programs and measures is $59.3 \%$, the substitution effect is $0.6 \%$, the displacement effect is $4.1 \%$, and the "deadweight" effect is $40.1 \%$, it can be concluded that the final net effect has the value of 14.5 p.p.

The study of the net effects by the main socio-demographic groups of unemployed persons allows not only to assess where the programs and measures on the labour market have been more effective, but also to direct future efforts, according to the size 


\section{Journal of Contemporary Management Issues}

of the net effect. Unfortunately, the substitution and displacement effects cannot be studied for each socio-demographic group, as this would mean tracking by whom exactly each worker was replaced (for example, if a man was replaced by a woman, a young person by an older one, etc.), and what specific competitive advantage each employee has provided to every company or organization, which is impossible.

For this reason, the assessments presented below are from the test and control groups. The effects are the gross effect, the "deadweight" effect and the net effect, respectively. The substitution and displacement effects were used in the evaluations of the individual programs and measures. It should also be taken into account that the programs and measures are aimed primarily at vulnerable groups in the labour market and in this sense, there is another effect, which is included in the study of the net effects of programs and measures, but not included in the following tables. In particular, this is the effect of targeting programs and measures, i.e. the effect resulting from the fact that labour market programs and measures are targeted at vulnerable groups. The net effects, according to gender are given in Table 3 .

Table 3. Net effects of the programs and measures according to gender

\begin{tabular}{|l|c|c|c|}
\hline Gender & Test group (\%) & Control group (\%) & Net effect (p.p.) \\
\hline Male & 54.4 & 36.8 & 17.6 \\
\hline Female & 62.3 & 42.7 & 19.6 \\
\hline
\end{tabular}

Source: Own estimations.

As demonstrated by the above table, the gross effects for women from the test group are higher than for men, while the effects on men and women in the control group are relatively close, with a difference of just about 6 p.p. The net effect for women is significantly higher than for men. Given the fact that the number of women registered as unemployed is higher than that of men and that programs and measures have a greater net effect on women, in the future it is advisable to focus more efforts on programs and measures for women.

In line with preliminary expectations, the higher education level provides higher chances for getting a job on the labour market. This has been noticed in both the test and the control groups. Persons with upper secondary and higher education achieve find jobs relatively easily, even without participating in programs and measures. However, this is not the case with the persons without primary or no education.

The highest net effect can be seen among those with primary or no education - 24.6 p.p, and those with lower secondary education - 19.3 p.p. The probable cause for this higher net effect is that it is very difficult for people, without or with a low level of education, to find a job, with a high amount of discouraged people among them, who lack confidence in the process of job seeking. In addition, the estimated net effect is the lowest among persons with higher/university education, who can find a job, without being included in the programs and measures. The net effects according to the level of education of the unemployed are given in Table 4. 
Table 4. Net effects of the programs and measures according to level of education

\begin{tabular}{|l|c|c|c|}
\hline Education & Test group (\%) & Control group (\%) & Net effect (p.p.) \\
\hline Primary or no education & 43.1 & 18.5 & 24.6 \\
\hline $\begin{array}{l}\text { Lower secondary } \\
\text { education }\end{array}$ & 43.9 & 24.6 & 19.3 \\
\hline $\begin{array}{l}\text { Upper secondary } \\
\text { education }\end{array}$ & 61.7 & 43.8 & 17.9 \\
\hline $\begin{array}{l}\text { Higher/university } \\
\text { education }\end{array}$ & 68.9 & 58.2 & 10.7 \\
\hline
\end{tabular}

Source: Own estimations.

The net effects are also studied according to whether the individuals have a vocational qualification or a certificate for

vocational training for at least one profession or not. The results are presented in Table 5 .

Table 5. Net effects of the programs and measures according to vocational qualification

\begin{tabular}{|l|c|c|c|}
\hline Vocational qualification & Test group (\%) & $\begin{array}{c}\text { Control group } \\
\mathbf{( \% )}\end{array}$ & Net effect (p.p.) \\
\hline $\begin{array}{l}\text { They have one or more vocational } \\
\text { qualifications }\end{array}$ & 64.4 & 46.9 & 17.4 \\
\hline They have no vocational qualification & 51.1 & 30.4 & 20.7 \\
\hline
\end{tabular}

Source: Own estimations.

When the individuals have a vocational qualification, or a certificate of vocational training for at least one profession, it is easier for them to find a job. As Table 5 shows, the net effect for the persons without vocational qualifications is 20.7 p.p., which is higher, when compared to those with vocational qualification - with a net effect of 17.4 p.p. In order to achieve a higher net effect, labour market programs and measures should be targeted at people without a vocational qualification, as obtaining one would enable them to find a job more easily.

The next aspect of the analysis is according to the age of the unemployed, who are grouped into the following four age groups: (1) young people up to 24 years of age, (2) young people between 25 and 29 years of age, (3) people from 30 to 55 years of age, and (4) people above 55 years of age. It is noteworthy that the effects in both the test group and the control group, decreased with age.
The highest net effect can be seen among the young people up to 24 years of age (48.3 p.p The provision of incentives to the youngest participants on the labour market results in a very high effect, through their relatively quick subsequent realization. In the second place is the net effect among persons between 25 and 29 years 22.5 p.p. This is followed by the group of persons over 55 years of age -15.4 p.p. Their relatively high net effect is due to the fact that, without participation in active labour programs and measures it is relatively difficult for them to find jobs. In addition, high-impact programs, such as the National Retirement Support Program are also included here. The conclusion is that the inclusion of more young people and older people in the active labour programs and measures should also lead to high net effects in the future. 


\section{Journal of Contemporary Management Issues}

Table 6. Net effects of the programs and measures according to the age group

\begin{tabular}{|l|c|c|l|}
\hline Age group & Test group (\%) & Control group (\%) & Net effect (p.p.) \\
\hline Up to 24 years & 68.6 & 20.3 & 48.3 \\
\hline $25-29$ years & 64.8 & 42.3 & 22.5 \\
\hline $30-55$ years & 57.5 & 43.8 & 13.7 \\
\hline $55+$ years & 52.4 & 37.0 & 15.4 \\
\hline
\end{tabular}

Source: Own estimations.

The next aspect of the analysis is ac- unemployed people live. The results are cording to the type of settlement where the presented in Table 7.

Table 7. Net effects of the programs and measures according to type of settlement

\begin{tabular}{|l|c|c|c|}
\hline Type of settlement & Test group (\%) & Control group (\%) & Net effect (p.p.) \\
\hline Sofia & 68.9 & 61.0 & 7.9 \\
\hline District towns & 67.4 & 49.5 & 17.9 \\
\hline Other towns & 52.9 & 40.1 & 12.8 \\
\hline Village & 46.8 & 23.4 & 23.4 \\
\hline
\end{tabular}

Source: Own estimations.

It is obvious that large towns provide more opportunities for getting a job than the smaller ones. This opportunity, of course, exists for both examined groups. The results show that the contribution of the ALMP is the smallest in Sofia (7.9 p.p.), and the largest in villages and district (regional) towns (respectively 23.4 p.p. and 17.9 p.p.). This may happen, due to the fact that, without programs and measures, it would be very difficult to find work in the villages. The smallest net effect is observed in Sofia which, being the capital city, offers the highest job opportunities, which can benefit the unemployed even without participating in the studied programs and measures.

Duration of unemployment also influences the opportunities for subsequent employment. The results are presented in Table 8.

Table 8. Net effects of the programs and measures according to the duration of unemployment

\begin{tabular}{|l|c|c|c|}
\hline Duration of unemployment & Test group (\%) & Control group (\%) & Net effect (p.p.) \\
\hline Up to 5 months & 68.0 & 55.9 & 12.1 \\
\hline From 6 to 11 months & 59.7 & 43.2 & 16.5 \\
\hline From 12 to 23 months & 57.2 & 34.4 & 22.7 \\
\hline Over 24 months & 40.0 & 16.8 & 23.2 \\
\hline
\end{tabular}

Source: Own estimations. 
As shown in Table 8, for both test and control groups, the possibility of employment decreases, with the increase in the duration of unemployment. It is impressive to see that the net effect increases with the increase in the duration of unemployment. This is mainly, due to the fact that the longterm unemployed from the control group find it very difficult to find a job, so ALMP should be targeted at this group.

Some of the programs and measures are targeted at people with reduced working capacity. Table 9 shows the net effects of the programs and measures according to the working capacity.

Table 9. Net effects of the programs and measures according to the working capacity

\begin{tabular}{|l|c|c|c|}
\hline Ability to work & Test group (\%) & Control group (\%) & Net effect (p.p.) \\
\hline Reduced & 41.2 & 17.7 & 23.5 \\
\hline Unreduced & 61.4 & 47.4 & 14.0 \\
\hline
\end{tabular}

Source: Own estimations.

Naturally, finding a job on the labour market is more difficult for the people with reduced working capacity. That is why a number of active labour market programs and measures are aimed specifically at them, such as the National Program for Employment and Training of People with Permanent Disabilities. This program encourages employers to hire unemployed people under the age of 29 with permanent disabilities, as well as young people from social institutions, who have completed their education. In addition, this program encourages employers to create jobs to recruit unemployed people with permanently reduced working capacity.
According to the results, the persons with reduced working capacity in the test group are performing relatively well - over $40 \%$ of them have started to work, while this share in the control group is $17.7 \%$. Therefore, the net effect of programs and measures for people with reduced working capacity is higher than for the people without reduced working capacity. This means that besides their social effect, the programs and measures directed towards people with reduced working capacity are also very effective, and therefore should be used even more actively in the future.

The distribution of the net effect according to the ethnicity of the unemployed is presented in Table 10.

Table 10.Net effects of the programs and measures according to ethnicity

\begin{tabular}{|l|c|c|c|}
\hline Ethnic group & Test group (\%) & Control group (\%) & Net effect (p.p.) \\
\hline Bulgarian & 63.9 & 44.2 & 19.7 \\
\hline Turkish & 40.2 & 25.5 & 14.7 \\
\hline Roma & 39.9 & 15.6 & 24.3 \\
\hline Other/ No answer & 59.2 & 23.1 & 36.1 \\
\hline
\end{tabular}

Source: Own estimations. 


\section{Journal of Contemporary Management Issues}

The representatives of the Bulgarian ethnic group come out as the ones with the highest gross effect, but with the lowest net effect of 19.7 p.p. People from Turkish and Roma ethnic groups, who participated in the programs and measures performed equally well in the labour market, while Roma who did not participate in the programs and measures found it more difficult to find work. That is why the net effect for the Roma representatives is the highest (24.3 p.p.).

\section{CONCLUSION}

The paper emphasizes the impact of active labour market policy at the individual level, assessing the programs and measures included in the National Employment Action Plan in Bulgaria. The analysis includes an assessment of the gross effects obtained after the closure of the programs and measures, but it also provides assessment of some other effects, such as the "deadweight" effect, the effects of substitution and displacement, and ultimately the net effects are obtained only due to the active labour market policy. The net assessment provides an answer to the question of what the situation would be if the programs and measures on the labour market in Bulgaria were not implemented.

The research results allow us to draw some important conclusions. More than a half of the participants in the programs and measures for employment and training have achieved a long-term realization on the labour market through re-employment or starting their own business. The number of those retired, due to their participation in the programs and measures, should be added, which results in three out of five participants who have felt a positive effect of the given programs and measures
$(59.3 \%)$. The persons involved in the programs and measures on the labour market were approximately twice as likely to find a job than those who were not included in the programs and measures of the NEAP. The chance of finding subsequent employment for the women, who have gone through training and employment programs and measures, is significantly higher than that of the men. Young people have the best chances of subsequent employment. With a higher age, it becomes more difficult to enter the labour market later, although there are active labour market programs and measures with a significant impact on older people, as well.

The higher the education of the people involved in the programs and the measures, the easier it is for them to enter the labour market. People with higher education are significantly more successful than those with primary or no education. On the other hand, active labour market policy contributes the most to people with low education, as their participation in programs and measures helps them to enter more easily the labour market. Although the gross effect of the subsequent employment of the people without or with very low levels of education is not large, the net effect is the most significant, especially for those with primary or no education, so that in the future the active labor market policies in Bulgaria must continue to be focused on these groups. This is their main chance to achieve employment.

Although the ex-post evaluation of the effect of active labour market policy is conducted separately for all programs and measures included in NEAP 2015, active labour market policy needs to be considered in a comprehensive and integrated way. The active labour market policy in Bulgaria focuses on two main segments: 1) an 
economic segment, covering these groups of unemployed people who can be employed relatively quickly, after their participation in the programs and measures, and 2) a social segment that includes vulnerable people in the labour market, who will find it very difficult to find a job without participating in programs and measures. The two segments share some aspects. Over the last few years, there has been an increase in the net effect of ALMP in Bulgaria, which is mainly due to those people with primary and no education, as well as those people living in the villages. This means that in the future, active labour market policy must pay special attention to these people.

Ultimately, a balance between those two segments must be sought in the active labour market policy. Active programs serve different purposes and policy makers need to be aware of their priorities. The analysis shows that in Bulgaria it is necessary to maintain the variety of different programs and measures on the labour market, covering different target groups, to which the present study contributes. For example, different programs and measures should be employed in the periods of unemployment decline and in situations of unemployment increase.

The current economic orientation of ALMP in Bulgaria is to achieve moderate cyclical declines, to reduce structural imbalances or otherwise improve the functioning of the labour market, to increase productivity, to provide support to disadvantaged or at-risk workers, or some combination of the above. Different types of active labour market programs and measures and different client populations are defined for each of these purposes. The challenge for the Bulgarian government is based on the existing experience to invest in labour market programs or measures that have a positive return, and to change, update or remove programs or measures that do not have such a return. In order for the active labour market policy in Bulgaria to be economically viable, it is very important for the national government to carefully and continuously evaluate its own programs and measures and to implement interventions based on those programs and measures that actually work and are effective.

\section{References}

1. Antony, J., Viles, E., Torres, A.-F., Incerti, T., Fernandes, M. M., Cudney, E. A. (2020), Design of experiments in the service industry: a critical literature review and future research directions, Total Quality Management (TQM), 32 (6), 1159-1175.

2. Arellano, A.F. (2010), Do Training Programmes get the unemployed back to work? A look at the Spanish experience, Revista de Economia Applicada, 18 (53), 39-65.

3. Ashenfelter, O. (1987), The Case for Evaluating Training Programs with Randomized Trials, Economics of Education Review, 6, 333-338.

4. Ashenfelter, O., Card, D. (1985), Using the Longitudinal Structure of Earnings to Estimate the Effect of Training Programs, Review of Economics and Statistics, 67, October, 648-660.

5. Ashenfelter, O., Harmon, C., Oosterbeek, H. (1999), A review of estimates of the schooling/earnings relationship, with tests for publication bias, Labour Economics, 6, 453-470.

6. Atanassov, A. (2016), Assessment of Active Labour Market Policies in Bulgaria: Evidence from Survey Data, Economic Alternatives, 3, 353-366. 


\section{Journal of Contemporary Management Issues}

7. Atanassov, A. (2017), A QuasiExperimental Approach to Assessing Net Effect in Active Labour Market Policy in Bulgaria, Conference Proceedings of the $6^{\text {th }}$ International Conference on Application of Information and Communication Technology and Statistics in Economy and Education (ICAICTSEE - 2016), December 2-3, 2016, University of National and World Economy (UNWE), Sofia, Bulgaria.

8. Bamberger, M. (2006), Conducting Quality Impact Evaluations under Budget, Time and Data Constraints, World Bank, Washington D.C.

9. Bassanini, A., Duval, R. (2006), Employment Patterns in OECD Countries: Reassessing the Role of Policies and Institutions, OECD Social, Employment and Migration Working Paper No. 35, June, Directorate for Employment, Labour and Social Affairs, OECD, Paris.

10. Bell, S.H., Orr, L.L., Blomquist, J.D., Gain, G.G. (1995), Methods Used to Evaluate Employment and Training Programs in the Past, Upjohn Research, No. 1-1-1995, Upjohn Press Book Chapters, Upjohn Institute Publications, W.E. Upjohn Institute for Employment and Research.

11. Benus, J., Rodriguez-Planas, N. (2002), Impact of Active Labor Market Programs, Prepared for Government of Romania, Ministry of Labor and Social Protection.

12. Besley, T., Case, A. (2000), Unnatural Experiments? Estimating the Incidence of Endogenous Policies, Economic Journal, 110, 672-694.

13. Betcherman, G., Olivas, K., Dar, A. (2004), Impacts of Active Labor Market Programs: New Evidence from Evaluations with Particular Attention to Developing and Transition Countries, Social Protection Discussion Paper Series, No. 0402, January, Social Protection Unit, Human Development Bank, The World Bank, Washington, D.C.

14. Blundell, R., Costa Dias, M. (2000), Evaluation Methods for Nonexperimental Data, Fiscal Studies, 21, 427-68.

15. Boone, J., Van Ours, J.C. (2009), Bringing Unemployment Back to Work: Effective Active Labor Market Policies, De Economist, 157, 293-313.

16. Borate, N.S., Gopalkrishna, Dr., Prasad, S., Borate, S.J. (2014), A Case Study Approach for Evaluation of Employee Training Effectiveness and Development Program, The International Journal of Business \& Management, 2 (6), 201-210.

17. Borland, J., Tseng, Y.-P., Wilkins, R. (2005), Experimental and quasi-experimental methods of microeconomic program and policy evaluation, Melbourne Institute Working Paper, Melbourne Institute of Applied Economic and Social Research, The University of Melbourne.

18. Bracken, P. (2006), Net Assessment: A Practical Guide, Commonwealth Institute, Spring.

19. Brown, A. J. G., Koettl, J. (2015), Active labor market programs - employment gain or fiscal drain, IZA Discussion Paper No. 12, Institute for the Study of Labor (IZA), Springer.

20. Card, D., Kluve, J., Weber, A. (2009), Active Labor Market Policy Evaluations: A Meta-Analysis, IZA Discussion Paper No. 4002, February, Institute for the Study of Labor (IZA), Bonn. 
Management, Vol. 25, 2020, No. 2, pp. 263-290 A. Atanassov, S. Trifonova: ASSESSMENT OF THE NET EFFECT OF THE ACTIVE LABOUR ...

21. Card, D., Sullivan, D. (1988), Measuring the Effect of Subsidized Training Programs on Movements In and Out of Employment, Econometrica, 56 (3), 497-530.

22. Calmfors, L. (1993), Lessons from the Macroeconomic Experience of Sweden, European Journal of Political Economy, 9 (1), 25-72.

23. Calmfors, L. (1994), Active Labour Market Policy and Unemployment - A Framework for the Analysis of Crucial Design Features, OECD Economic Studies, No 22, OECD, Spring, Paris.

24. Calmfors, L., Nymoen, R. (1990), Real Wage Adjustment and Employment Policies in the Nordic Countries, Economic Policy, 5 (11), 397-448.

25. Dar, A., Tzannatos P. Z. (1999), Active Labor Market Programs: A Review of the Evidence from Evaluations, Social Protection Discussion Papers, No. 9901, January, The World Bank. Washington, D.C.

26. Dinardo, J. (2008), Natural experiments and quasi-natural experiments. The New Palgrave Dictionary of Economics, 856-859.

27. Econometrica Ltd. (2017), Report on a project entitled Elaboration of a Subsequent Assessment of the Effect of the Active Labour Market Policy Financed by State Budget Resources at Individual Level (Net Effect), Ministry of Labour and Social Policy of the Republic of Bulgaria.

28. Employment Promotion Act, Promulgated, State Gazette, issue 112 of December 29, 2001, In force since 01.01.2002.

29. Eriksson, T., Suvanto, A., Vartia, P. (1990), Wage formation in Finland, In: Wage Formation and Macroeconomic Policy in the Nordic Countries,
Calmfors, L. (ed.), SNS and Oxford University Press.

30. Fay, R.G. (1996), Enhancing the Effectiveness of Active Labour Market Policies: Evidence from Programme Evaluations in OECD Countries, Labour Market and Social Policy Occasional Papers No. 18, OECD, Paris.

31. Fitzenberger, B., Prey, H. (2000), Evaluating Public Sector Sponsored Training in East Germany, Oxford Economic Papers, 52 (3), 497-520.

32. Forslund, A., Krueger, A. B. (1994), An Evaluation of the Swedish Active Labor Market Policy: New and Received Wisdom, National Bureau of Economic Research (NBER) Working Paper No. 4802, July.

33. Fraker, T., Maynard, R. (1987), The Adequacy of Comparison Group Designs for Evaluations of Employment-Related Programs, Journal of Human Resources, 22 (2), 194-227.

34. Fretwell, D. F., Benus, J., O'Leary, Ch. J. (1999), Evaluating the Impact of Active Labor Programmes: Results of Cross Country Studies in Europe and Central Asia, Social Protection Discussion Paper, No. 9915, The World Bank, June.

35. Friedlander, D., Greenberg, D.H., Robins, P.K. (1997), Evaluating government training programmes for the economically disadvantaged, Journal of Economic Literature, 35 (4), 1809-1855.

36. Glitz, A. (2011), The Labor Market Impact of Immigration: A QuasiExperiment Exploiting Immigrant Location Rules in Germany, Universitat Pompeu Fabra and Barcelona GSE, January. 


\section{Journal of Contemporary Management Issues}

37. Greenberg, D. H., Michalopoulos, C., Robins, P. K. (2003), A meta-analysis of government sponsored training programs, Industrial and Labour Relations Review, 57 (1), 31-5.

38. Grubb, W.N. (1995), Evaluating job training programmes in the United States: evidence and explanations, Technical Assistance Report, University of California at Berkeley National Center for Research in Vocational Education, May.

39. Haveman, R., Hollister, R. (1991), Direct job creation: economic evaluation and lessons for the United States and Western Europe, In: Labour Market Policy and Unemployment Insurance, Bjorklund, A. et al. (eds.), FIEF Studies in Labour Market and Economic Policy, Oxford University Press.

40. Heckman, J. J., (1999), Causal Parameters and Policy Analysis in Economics: A Twentieth Century Retrospective, National Bureau of Economic Research (NBER) Working Paper No. 7333, September.

41. Heckman, J. J., Ichimura, H., Smith, J. A., Todd, P. (1998), Characterizing Selection Bias Using Experimental Data, Econometrica, 66, 1017-1098.

42. Heckman, J. J., Lalonde, R. J., Smith, J. A. (1999), The Economics and Econometrics of Active Labor Market Programs, In: Handbook of Labor Economics, Ashenfelter, O. and Card, D. (eds.), Vol. 3A, Elsevier.

43. Heckman, J. J., Robb, R. (1985), Alternative Methods for Evaluating the Impact of Interventions, In: Longitudinal Analysis of Labor Market Data, J. J. Heckman and B. Singer (eds.), Cambridge: Cambridge University Press, 156-246.
44. Imbens, G. M. (2004), Nonparametric Estimation of Average Treatment Effects under Exogeneity: A Review, Review of Economics and Statistics, 86, 4-29.

45. Imbens, G.M., Wooldridge, J.M (2008), Recent Developments in the Econometrics of Program Evaluation, National Bureau of Economic Research (NBER) Working Paper No. 14251, August.

46. Johannesson, J., Wadensjo, E. (1995), Labour Market Policy on Unemployment, In: Jan Johannesson and Eskil Wadensjo (eds.).

47. Kish, L. (1965), Survey Sampling, John Wiley \& Sons, Inc.

48. Kluve, J. (2007), The Effectiveness of European ALMP's, In: Active Labor Market Policies in Europe: Performance and Perspectives, Kluve, J. et al. (eds.), Springer,153-203.

49. Kluve, J. (2010), The Effectiveness of European active labor market programs, Labour Economics, 17, 904-918.

50. Krishnamoorthy, S., Kapadia, M. M. (1999), A methodology on enhancing profitability through the utilization of experimental design: a catering business case study, Total Quality Management, 10 (7), 1027-1036.

51. Lewis, P., Ryan, C. (1985), Wage Subsidies, Their Employment Effects and How to Evaluate Them, Bureau of Labour Market Research Working Paper, No. 51, Canberra.

52. Lalonde, R. J. (1986), Evaluating the Econometric Evaluations of Training Programs with Experimental Data, American Economic Review, 76, 604-620.

53. Martin, J. P. (2000), What Works among Labor Market Policies: 
Management, Vol. 25, 2020, No. 2, pp. 263-290 A. Atanassov, S. Trifonova: ASSESSMENT OF THE NET EFFECT OF THE ACTIVE LABOUR ...

Evidence from OECD Countries' Experiences, OECD Economic Studies, 30 (1), 80-111.

54. Martin, J.P., Grubb, D. (2001), What Works and For Whom: A Review of OECD Countries' Experiences with Active Labour Market Policies, Swedish Economic Policy Review, 8 (2), 9-56.

55. Meyer, B. (1995), Natural and quasiexperiments in economics, Journal of Business and Economics Statistics, 13, 151-161.

56. Ministry of Labour and Social Policy of the Republic of Bulgaria (2015), Assessment of the Effect of the Active Labour Market Policies at Individual Level, Under a Project BG051P0001-6.1.11 Elaboration of an Impact Assessment of the Active Labour Market Policies Financed by State Budget under Human Resources Development Operational Programme 2007-2013, co-financed by the European Social Fund of the European Union, Sofia.

57. Ministry of Labour and Social Policy of the Republic of Bulgaria (2019), Elaboration of a Subsequent Assessment of the Effect of the Active Labour Market Policy Financed by State Budget Resources at Individual Level (Net Effect) of the Programs and Measures, Included in the National Employment Action Plan for 2017, Under a Project BG05M9OP001-1.007-0001 Increasing the effectiveness of the implemented employment policy under Human Resources Development Operational Programme 2007-2013, co-financed by the European Social Fund of the European Union, Sofia.

58. Ministry of Labour and Social Policy of the Republic of Bulgaria (2015),
National Employment Action Plan of the Republic of Bulgaria in 2015, adopted by Decision of the Council of Ministers No. 14 of 14.01.2015.

59. Mitchell, O. (2016), Experimental Research Design, In: The Encyclopedia of Crime and Punishment, $1^{\text {st }}$ ed., Jennings, W. G. (ed.), John Wiley \& Sons, Inc.

60. Moffitt, R. (1992), Evaluation Methods for Program Entry Effects, In: Evaluating Welfare and Training Programs, Manski, C., Garfinkel, I. (eds.), Harvard University Press, 231-252.

61. OECD (1993), Employment Outlook Towards More and Better Jobs, OECD, Paris.

62. Payne, J. (2000), Evaluating Training Programmes for the Long-Term Unemployed, PSI Research Discussion Paper No. 1, Policy Studies Institute (PSI), PSI Report No. 871, London.

63. Payne, J., Payne, C., Lissenburgh, S., Range, M. (1999), Work-Based Training and Job Prospects for the Unemployed: An Evaluation of Training for Work, Department for Education and Employment Research Report RR96, Sheffield.

64. Park, N., Power, B., Riddell, W.C., Wong, G. (1996), An Assessment of the Impact of Government-Sponsored Training, Canadian Journal of Economics, 29 (Special Issue: Part 1), S93-S98.

65. Peirce, C.S. (1883), A Theory of Probable Inference, In: Studies in Logic by Members of the Johns Hopkins University, Peirce, C. S. (ed.), Little, Brown, and Company, Boston, 126-181. 


\title{
Journal of Contemporary Management Issues
}

66. Peirce, C.S. (1877-1878), Illustrations of the Logic of Science (series), Popular Science Monthly, 12-13.

67. Raaum, O., Torp, H. (2000), Labour Market Training in Norway - Effect on Earnings, Department of Economics, University of Bergen, Oslo.

68. Riddell, C. (1998), Quasi-experimental Evaluation, Report prepared for Human Resources Development Canada, SP-AH053E-01-98.

69. Rodriguez-Planas, N., Benus, J. (2010), Evaluating Active Labor Market Programs in Romania, Empirical Economics, 38, 65-84.

70. Rosenbaum, P.R., Rubin, D.B. (1983), The Central Role of the Propensity Score in Observational Studies for Causal Effects, Biometrika, 70, 41-55.
71. Ross, S., Morrison, G.R. (2003), Experimental Research Methods, AECT, January, 1021-1043.

72. Schmidt, C. (1999), Knowing What Works: The Case for Rigorous Program Evaluation, IZA Discussion Paper, No. 77, Institute for the Study of Labor (IZA), Bonn.

73. Sahnoun, M., Abdennadher, C. (2018), The assessment of active labor market policies: evidence from OECD countries, Econ Polit, Springer International Publishing AG.

74. Smith, J. (2001), A Critical Survey of Empirical Methods for Evaluating Active Labor Market Policies, Swedish Economic Review, 136, 1-22.

\section{PROCJENA NETO UČINKA AKTIVNE POLITIKE ZAPOŠLJAVANJA U BUGARSKOJ}

\begin{abstract}
Sažetak
Procjena neto efekta aktivne politike zapošljavanja doprinosi efektivnoj uporabi javnih sredstava, kako bi se postigli optimalni rezultati i osigurale mogućnosti budućih promjena prioritetnih područja $u$ akcijskim planovima zapošljavanja. U ovom se radu analiziraju osnovni koncepti za procjenu neto efekta aktivne politike zapošljavanja i procjenjuju njeni neto efekti u Bugarskoj. U okviru procjene djelovanja aktivne politike zapošljavanja na individualnoj razini, za svaki program i mjeru, uključenu u nacionalni akcijski plan zapošljavanja iz 2015. godine te financiranu iz državnog budžeta, procjenjuju se ukupni, rezidualni, supstitucijski i zamjenski efekti. Za procjenu neto efekta programa i mjera na tržište rada u Bugarskoj, koristi se kvazi-eksperimentalni istraživački nacrt. Rezultati procjene govore da ukupni neto efekt iznosi 14,5\%. Za žene, on je značajno veći, negoli za muškarce. S aspekta obrazovanja, najveći neto efekt odnosi se na osobe s osnovnim, ili bez formanog obrazovanja. Kada se promatra dob, najveći neto efekt se primjećuje za mlade do 24 godine starosti. Vezano uz trajanje nezaposlenosti, najveći se neto efekt može primijetiti kod dugoročno (dulje od 24 mjeseca) nezaposlenih osoba. Što se tiče sposobnosti za rad, najveći neto efekt je prisutan kod osoba sa smanjenom sposobnošću, a s aspekta vrste naselja - u ruralnim područjima. U radu se iznosi određeni broj zaključaka i preporuka za povećanje efektivnosti aktivnih politika zapošljavanja i unapređenje tržišta radne snage u Bugarskoj. Analiza pokazuje da je u Bugarskoj potrebno održavati različite programe i mjere na tržištu rada, kojima se ciljaju i različite ciljne skupine.
\end{abstract}

Ključne riječi: aktivna politika zapošljavanja, neto efekt, procjena, programi i mjere za smanjenje nezaposlenosti 